\section{Lembaran Sejarah}

\title{
Colonial Print Culture: Sundanese Book Publishing in the Dutch East Indies in the Early Twentieth Century
}

\section{MIKIHIRO MORIYAMA}

Nanzan University

Email: moriyama@nanzan-u.ac.jp

\begin{abstract}
The indigenous book publishing business for Sundanese-speaking communities started in the early 20th century, when the nationalist movement was set in motion. The modern school system had continued to spread in colonial society from the mid19th century. The more education spread, the more literate people there were among the indigenous population. The indigenous book publishing business responded to the demands of this newly-emerging readership. Book publishing finally turned into a business by the 1920s. It seems to have provided distinctive readings from those provided by Balai Poestaka. The indigenous publishers played a supplemental role in nurturing print culture in the colonial context. Both government and private indigenous publishers contributed to promote modern readership and a colonial print culture. The book publishing and print culture in regional languages like Sundanese were nurtured in the colonial period and grew to constitute a medium to decolonize knowledge and knowledge culture.
\end{abstract}

\begin{abstract}
Abstrak
Bisnis publikasi buku-buku pribumi untuk masyarakat berbahasa Sunda dimulai semenjak awal abad ke-20, pada periode ketika gerakan nasionalisme mulai berjalan. Sistem sekolah modern telah menyebar dalam masyarakat kolonial semenjak kemunculannya pada pertengahan abad ke-19. Seiring dengan persebaran pendidikan, maka semakin banyak pula kalangan terpelajar dalam masyarakat pribumi. Bisnis publikasi buku ini merespon terhadap permintaan dari pembaca yang sedang naik daun ini. Publikasi buku berkembang menjadi bisnis semenjak tahun 1920an. Pencetak pribumi memainkan peranan pembantu dalam mendorong kemunculan pembaca modern dan budaya percetakan kolonial. Budaya publikasi dan percetakan buku dalam bahasa daerah seperti Sunda berkembang pada periode kolonial dan menjadi salah satu medium yang berguna dalam mendekolonisasi pengetahuan dan budaya pengetahuan.
\end{abstract}

Keywords: colonialism; print culture; Sundanese; the Dutch East Indies; West Java

Kata kunci: budaya percetakan; Hindia Belanda; Jawa Barat; kolonialisme; Sunda 


\section{Introduction ${ }^{1}$}

Sundanese book printing started around 1850 and continues to the present. The publication of Sundanese writing was initiated by the Dutch colonial government to help manage the colony. ${ }^{2}$ Schools were established and books were published to educate the "indigenous people" so the government could it turn select and train local officials. In 1908 a government-subsidized institution, Commissie voor de Inlandsche School- en Volkslectuur (Committee for Indigenous Schools' and People's Reading), in light of the growing rate of literacy in the Indies, sought to provide "good" and "appropriate" reading materials. This institution then changed its name to Balai Poestaka in 1917, which continued to publish in Sundanese and other local languages even after independence. ${ }^{3}$

Besides the colonial government's publishing endeavors, some books in indigenous languages, such as Sundanese, were also published by local nongovernment publishers, although the number of their publications was not as high as that of Balai Poestaka. Still, a small number of toko boekoe (bookstores) began to be established that printed, published and sold Sundanese books in the early 20th-century West Java. The toko boekoes were owned and managed by Dutch, Chinese and the indigenous people(mostly Sundanese) in West Java. This article will focus on the activities of one of the toko boekoes managed by a Sundanese, to book publishing in the colony in terms of printing, distributing, and selling, amid a growing interest in reading among a potential reading community. The activities of the indigenous printers and publishers established a foundation for Indonesian publishing that burgeoned after independence. It can be said that the book publishing and print culture in indigenous and regional languages like Sundanese and Javanese - besides Malay - had been nurtured in the colonial period and likely constituted a medium to decolonize knowledge and knowledge culture. However, indigenous entrepreneurs in particular, faced difficulties in producing books. ${ }^{4}$ It is noteworthy that the indigenous publishing businesses were different to the government-owned publisher Balai Poestaka in terms of book quality and

1) This article is written based on the author's presentation at the international workshop "The Construction of Indonesian Knowledge Cultures Since Independence" held at Universitas Gadja Mada in Yogyakarta on 5 and 6 February 2020. This research is supported in part by grants from JSPS (Kiban Kenkyu C) for 2016-2020 and Nanzan University Pache Research Subsidy I-A-2 for the 2021 academic year.

2) The data and part of this article overlap with Moriyama's books $(2005 ; 2013)$ and articles $(2017,2018)$, as it is a continuing and developing discussion of previous research.

3) Balai Poestaka had played a role in censoring indigenous publications, in particular the vernacular press, amidst growing literacy among the indigenous population, yet did not fulfil this role as intended by the colonial government (Yamamoto, 2019: 62-78, 153-175).

4) This point was argued by E. Kortekaas at the international workshop (see footnote 1). 
content. The indigenous publishers produced far simpler and poorer quality books, and the content was much freer and closer to reader's interests, with different norms and values compared to Balai Poestaka's publications.

\section{Overview of Sundanese Printed Books in the Early Twentieth Century}

The first book printed in Java was in Dutch, in the middle of the 17th century (Graaf, 1969: 12). Not until the mid-18th century were books printed in indigenous languages, first in Malay, the language of communication in the Archipelago then in Javanese, the main language of Java the island where Dutch activities were concentrated. It would be another hundred years before the first Sundanese books began to appear (AVSS 1853: 320-367). The number of printed books in Sundanese - mainly schoolbooks - was to remain relatively small. Malay and Javanese were seen as more important languages and given a higher priority until the end of the colonial era. Sundanese publications for the first century amount to about five hundred titles comprising about 640 editions, ${ }^{5}$ mostly in Sundanese and presumably published for Sundanese readers. ${ }^{6}$

Most publications were printed in Batavia (later Jakarta) and cities in the province of West Java. In the 19th century most books were published by the colonial government or missionaries. Most of them were printed in Batavia or alternatively in the Netherlands because of the limited number of typographic printing machines, which were mostly owned by the government enterprise Landsdrukkerij or by Dutch Christian missionaries who had access to print technology. Meanwhile, lithographic printing of books in Sundanese had started around the same period in and around Muslim communities in the Dutch and British colonies (Moriyama, 2005: 77-93). In the early 20th century most publications were still printed in Batavia by the colonial government through the Commissie voor Volkslectuur from 1908, and Balai Poestaka after 1917. Local publications gradually emerged from the 1910s onwards and established printing facilities in cities in the province of West Java, particularly in Bandung, the biggest city. A small number of private

5) This writer's research was mainly conducted at Leiden University library, which houses the collections of the KITLV/Royal Netherlands Institute of Southeast Asian and Caribbean Studies and the KIT/Royal Tropical Institute. This writer also researched the collections of Perpustakaan Nasional in Jakarta and Perpustakaan Museum Konferensi Asia Afrika in Bandung.

6) Bilingual works in Sundanese and Dutch or Malay and other languages are included for a Sundanese readership. Hence dictionaries and glossaries are included, as are grammar books and other didactic materials only if intended for use by Sundanese. Manuals, grammar books, dictionaries and conversation guides for Dutch or other nonSundanese are not included. Non-book ephemera such as posters, charts, invitation cards and the like are not included in this research either. This article will discuss only printed books, not periodicals in Sundanese. 
printing houses and publishers operated in the cities of Tasikmalaya, Garut, Cirebon, Sukabumi and Batavia.

Three distinct scripts were used for Sundanese printed books: Javanese, ${ }^{7}$ Roman (huruf Walanda or the 'Dutch alphabet' in Sundanese) and Arabic (Pegon in Sundanese). In this early period of printing a considerable number of books were printed in Javanese script because a government advisor on indigenous affairs, K.F. Holle, had the idea that Javanese script was preferable for printing Sundanese books, given the literacy level of the potential readers. Arabic script was never suggested because of a fear of it leading to "Islamic fanaticism" (Moriyama, 2005: 17).

As time went by, fewer books (and fewer total pages) were printed in Javanese script and more in Roman script. Apart from the above-mentioned political reasons - Roman script was associated with modernity - there were also economic ones: Javanese script needed double the space of Roman script. ${ }^{8}$ After 1902 Landsdrukkerij no longer published Sundanese books in either Javanese or Arabic script, except for some reprints. ${ }^{9}$

As to publications produced by indigenous printing houses and publishers, Roman script was mostly used for secular books. Arabic script was mostly used for lithographic printing of Islamic content, known as kitab kuning (Bruinessen 1988; Proudfoot 1993). However, the surviving printed material in both Roman and Arabic script does not provide a clear enough picture, because a quite few number of publications are missing, in particular publications in Arabic script. The distinction of usage of script is a tendency only.

\section{Printing and Publishing Sundanese Books}

\section{Government Printing House Landsdrukkerij and Balai Poestaka}

Judging from the number of publications, over a period of about 100 years, the most significant role in publishing Sundanese books was played by government publishers. It seems that $90 \%$ of the publications were from Landsdrukkerij, and Balai Poestaka. Landsdrukkerij printed and published about 150 books and Balai Poestaka about four hundred books, including the titles of the Committee for Indigenous Schoolbooks and Popular Reading Books.

Balai Poestaka played a significant role in print culture in the first half of the 20th century, for example publishing 236 books between 1911 and

7) Javanese typography was developed in the 1820s and 1830s and used for printing in various languages in the Dutch Indies (Molen, 2000: 140-149).

8) For example, Wawacan Panji Wulung in Roman script only had 122 pages, while the Javanese script version had 266 (Moriyama, 2005: 90-92).

9) So-called Arabic literacy did not vanish but developed in parallel with the growth of Roman literacy. Up until the present day, Arabic script is used and sometimes also printed in Sundanese-speaking areas, especially in and around Islamic institutions. Javanese script has completely vanished in Sundanese-speaking areas. 

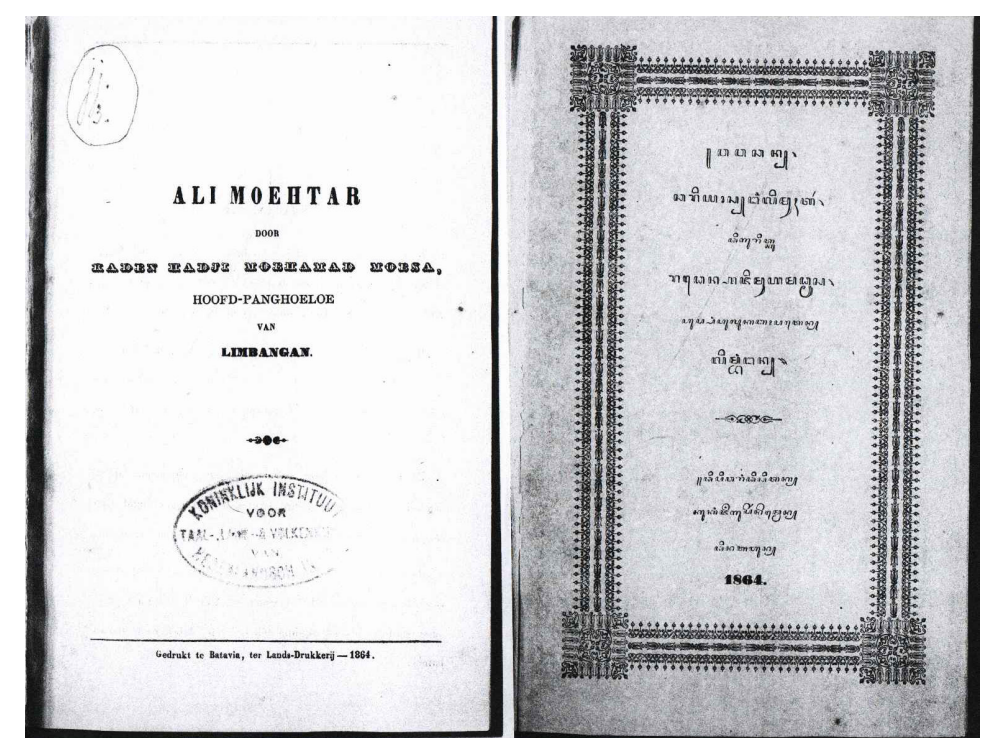

Figure 1. An early Sundanese book printed by Landsdrukkerij

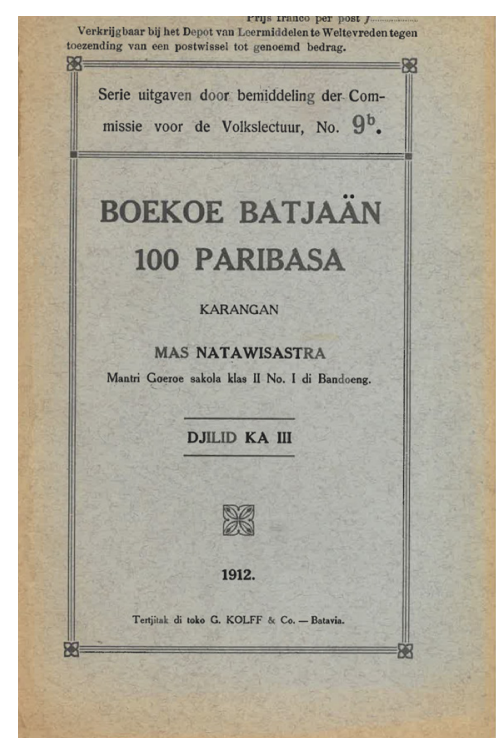

Figure 2. Cover page of a Sundanese book published by Balai Poestaka.

1916: 117 books in Javanese (49\%), 68 in Sundanese (29\%), 33 in Malay (14\%) and 18 in Madurese (8\%) (Balai Pustaka, 1948: 9). In the beginning, Balai Poestaka usually sent printing orders to Dutch or Eurasian and some Chinese commercial printing houses in Batavia. These private printing houses published Sundanese titles under the name Volkslectuur. Serie uitgaven door bemiddeling der Commissie voor de Volkslectuur (Popular reading: Series of publications by the Committee for Popular Reading Books), which appeared on the cover page (Figure 2). Most of these printing houses withdrew gradually from the business of printing Sundanese books, especially since Balai Poestaka itself tried to print books under director D.A. Rinkes's rationalization of activities since 1917. Balai Pustaka is deemed to have had an enormous impact in nurturing print culture in Sundanese, even though its content was selected and was subject to a degree of censorship.

\section{Indigenous Printing Houses and Publishers}

There doesn't seem to have been a market economy in the publishing business up until the early 20th century. Printing Sundanese books did not make money because there was a limited readership for these books. Most printed books were in Roman script and the level of literacy in that script was very low. Printing presses were also rare and expensive.

The situation seems to have changed by the 1920s. Local entrepreneurs began to participate in the publishing business, and population growth and increased literacy in the Indies may have supported their businesses. In 1914 the Hollandsch-Inlandsche School (HIS) (Dutch Indigenous Schools) was established, and in time more indigenous children attended these schools. 
The number of students in the schools was 22.477 in 1915, increasing to 58.785 by 1930 (Groeneboer, 1993: 488-489). In addition to this, the growing availability of printing presses and articles cannot be overlooked. As the conditions for publishing businesses evolved, books became a commodity in the Indies and thus publishers found opportunities to make a profit from printing books in Sundanese.

In fact, some printing houses and publishers owned by Dutch, Eurasian and Chinese people had existed in Batavia since the 19th century, as mentioned above. What was remarkable is that, next to these printing houses, since the 1910s indigenous printing houses sprang up rapidly (Moriyama, 1990: 115-116). These printing houses noticeably increased their production of Sundanese books in that decade.

We also need to bear in mind that these printing houses were responsible not only for printing books but also sometimes for compiling and editing them. There was no clear distinction between a printing house and publisher as is commonly understood. Toko boekoes not only sold books, they also edited and printed them. A good example of such a printing house was Drukkerij Dachlan-Bekti, located at Groote Postweg 23 in Bandung (Figure 3). Publishers who did not own their own printing press sent their orders to a printing house. Still, most printing houses in Batavia and Bandung only printed their Sundanese books - they did not edit or sell them - as Ruygrok in Weltevreden and Drukkerij Soenda in Bandung did. ${ }^{10}$

These business practices possibly derived from book publishing practices in the Netherlands. ${ }^{11}$ In the 19 th century a number of Dutch publishers from the Netherlands went to the colony to expand their businesses, such as G. Kolff and van Dorp who opened businesses in Batavia and other East Indies cities. It is plausible that indigenous publishers and toko boekoes learned business management practices from those Dutch commercial publishers.

In the 1910s and 1920s, most toko boekoes that published Sundanese books were in Bandung. Bandung was the biggest Sundanese-speaking city and was regarded as the cultural and political center of Sundanese culture

10) Other printing houses include N.V. Boekh. Visser \& Co. (Bandung), Drukkerij Aurora (Bandung), Druk. Galoenggoeng Tasik (Tasikmalaya), Indonesische Drukkerij (Weltevreden - proximate to Batavia), Papyrus (Weltevreden), Mangoen di Karia (Weltevreden), Albrecht \& Co (Weltevreden), Typ. Thetenghoey \& Co. (Buitenzorg), Fuhri \& Co. (Surabaya). Drukkerij en Boekhandel H.A. Benjamins in Semarang printed Sundanese books at some point but did not sell them, though they sold books printed in other languages.

11) Publishers in the Netherlands had a tradition of printing, publishing and selling their own books. However, as Kuitert mentions, "The all-in-one trader, who was both publisher and shopkeeper (and often printer as well) gave way in the nineteenth century to two new professions, distinct from each other: that of bookseller and that of publisher" (Kuitert,, 2001: 186-187). It seems that indigenous publishing in the Dutch East Indies inherited this practice, which continued up to the early 20th century. 


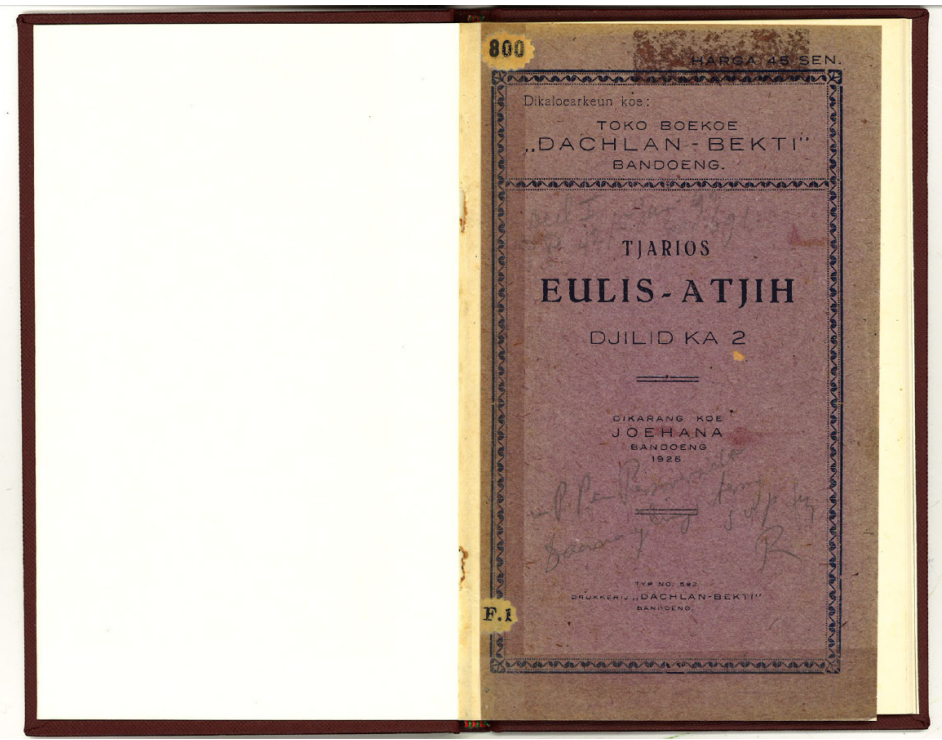

Figure 3. Tjarios Eulis-Atjih,

published by Dachlan-Bekti in 1925

since the middle of the 19th century. Table 1 lists indigenous publishers operating in Bandung during this period.

Table 1. Indigenous Publishers in decades 1910s and 1920s in Bandung

\begin{tabular}{cc}
\hline Toko boekoe M.I. Prawira-Winata & C. Nix \& Co, \\
Toko boekoe Dachlan-Bekti & V. De Bibliotheek \\
N.V. Sie Dhian Ho & Nochrawi Drukkerij Soenda \\
Insulinde & Drukkerij Economy \\
Sindang Djaja & Druk. N.V. Mij. Vorkink \\
Druk. H.M. Affandi & Penerbit N.V. Ma'arif \\
Kaoem Moeda & Nanie \\
Toko boekoe Union & Toko Kitab Sindang Djaja \\
N.V. Boekh. Visser \& Co. & Toko boekoe Pribumi \\
\hline
\end{tabular}

There were about twenty publishers in Bandung. Some toko boekoes published a considerable number of books, while others did not publish very many. In the next section one of the most productive publishers in the 1920s, Toko Boekoe M.I. Prawira-Winata, will be discussed in detail. There were also toko boekoes that published Sundanese books in other cities of West Java and Batavia (see Table 2).

Table 2. Indigenous Publishers in the period 1910-1920 in West Java and Batavia

\begin{tabular}{ll}
\hline Tasikmalaya: & Cirebon: \\
Toko Boekoe Pasoendan & Toko Boekoe Boerhan \\
D.A.S. Koernia Drukkerij & Batavia: \\
Soekapoera Drukkerij & Toko \& Drukkerij Lie Tek Long \\
Pagoejoeban Tjabang Tasikmalaja & Boekhandel Krakatau \\
Sukabumi: & Noordhoff-Kolf N.V. \\
Toko Boekoe Tjikiraj & G. Kolff \& Co \\
Garut: & Javasche Boekhandel en Drukkerij \\
Toko Boekoe M. Engka Widjaja & \\
Kantor Tjitak Het Boekendepot & \\
\hline
\end{tabular}




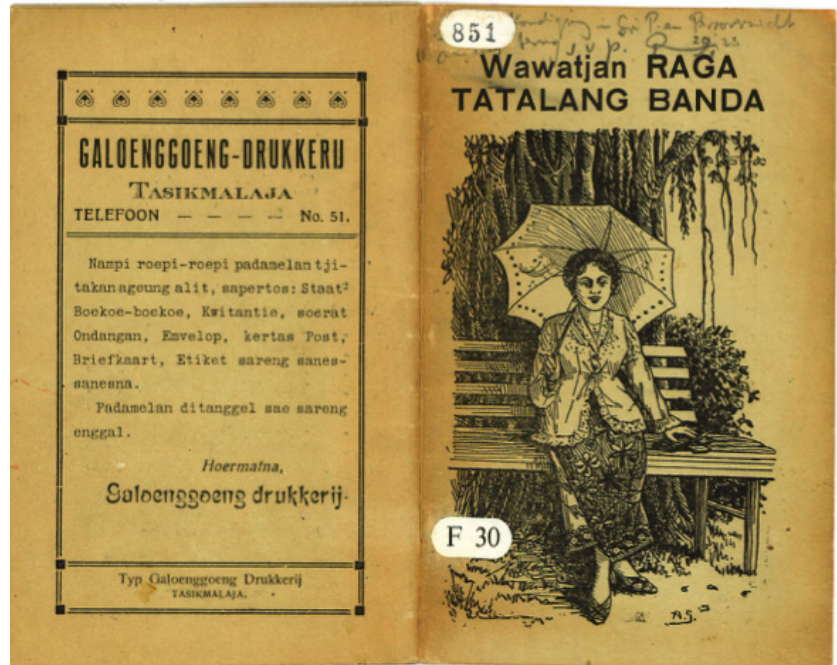

Figure 4. Wawatjan Raga Tatalang Banda published in 1922

It is noteworthy that at least four publishers also ran their businesses in Tasikmalaya, which was another political and cultural center of the province of West Java next to Bandung. They were not only publishers but also printing houses, such as Galoenggoeng Drukkerij, and were productive in this eastern Sundanese-speaking hub. For instance, Toko Boekoe Pasoendan in Tasikmalaya published eleven books in Sundanese such as Wawatjan Raga Tatalang Banda (A Story of the Body Possessed by Wealth, 1922) (see Figure 4). It is quite common for the last pages of a book to list books on sale, as an advertisement.

Another indigenous printing house in West Java, Kantor Tjitak Boekendepot Garoet, not only ran a printing business but also sold Dutch school books and Dutch-Sundanese and Dutch-Malay dictionaries for students learning at HIS. ${ }^{12}$ The books listed on the cover page of Tjarios Enden Djadja (The Story of Mrs Djadja), authored by the owner of the publishing house M. Engkawidjaja, suggests both a growth in the number of publications and the spread of modern school education among the local population even in Garut, a small neighboring city of Bandung. ${ }^{13}$ In the business of printing and publishing Sundanese books, few Chinese enterprises can be found in the early 20th century. One exception is Rengganis, a traditional story in verse published in 1920 by Toko \& Drukkerij Lie Tek Long in Batavia, which also published books in Malay. Advertisements for the book shows that the title

12) This printing house prepared school books for HIS such as Ot en Sien, Pim en Mien, Rood wit en blauw, Mijn Hollandschboek (Engkawidjaja [19xx]: cover page).

13) Books sold by Kantor Tjitak Boekendepot Garoet included Ilmoe Agama for $\mathrm{f}$. 2.50 (Malay), Gelap dan Terang for f. 2,-(Malay), Tjonto-tjonto Walanda-Soenda, Pengadjaran boekoe basa Soenda-Walanda, Pengadjaran boekoe basa Walanda-Soenda (Examples of DutchSundanese, Text book for Sundanese-Dutch language, Text book for Dutch-Sundanese language (Malay). 
could be purchased from their book agents in the province of West Java. ${ }^{14}$ There were 18 agents, ${ }^{15}$ which suggests that there existed a network of book agents that supplied a growing number of readers with books in indigenous languages as well as Dutch.

Meanwhile, a network of indigenous toko boekoes served to help sell each other's Sundanese books. For instance, a book titled Wawatjan Arjoenawidjaja (The Story of Arjoenawidjaja), published by Toko Boekoe Tjikiraj in Sukabumi, could be bought at Toko Boekoe M.I. Prawira Winata in Bandung, Toko Boekoe Boerhan in Cirebon, and five other toko boekoes, according to the advertisement placed on the cover page of Tjarios Tooneel Hojong Kagoengan Garwa Noe Anom (A Theatrical Story; I Wish to have a Young Wife) in 1926. It is clear that toko boekoes exchanged their books to be sold by each other, like the Dutch printing business used to do. These networks of toko boekoes and book agents in the Dutch East Indies nurtured literacy in the colonial era, which continued to develop after independence and played a significant role in creating a unique print culture.

In terms of legibility and quality of content, indigenous publications were usually inferior to Balai Poestaka publications and the distribution was poorer, but surprisingly the book prices were almost the same. ${ }^{16}$ The authors who contributed to the indigenous publications were mostly different to those who contributed to Balai Poestaka however, some contributed to both. For instance, books of Yoehana, a popular author, were published by Drukkerij Dachlan-Bekti as his stories of less moralistic and more sensational nature were more suited to private publishing than the government-owned Balai Poestaka. By contrast, Memed Sastrahadiprawira, a well-known man of letters and Dutch government official, was a good example of someone who wrote stories for publications in both Balai Poestaka and indigenous publishing houses. ${ }^{17}$

The authorities tried to control these indigenous publications, for the sake of order and peace in the colony, mainly through Balai Poestaka, but this was not an easy task. The books were printed everywhere and circulated

14) The advertisement of the book says, "Available now: you can buy Rengganis at our agents (Soeda ada sedia: Rengganis bole dapet beli pada saja poenja agent-agent)".

15) Seventeen of them seem to be Chinese agents, judging from their names. Bandung-based N.V. Sie Dhian Ho was another Chinese-owned publisher of Sundanese books. The researcher also found two Chinese commercial printing houses that printed Sundanese books by the order of Volkslectuur in Batavia that is, N.V. Elect. Drukk. Favoriet (est. 1915, Chinese-owned) and Kwee Khe Soei (est. around 1926).

16) The book prices of Balai Poestaka were mostly below $f 1.00$, according to the publication catalogue for 1921 Daftar Kitab-kitab jang dikeloerkan oleh Komisi Balai Poestaka di Weltevreden (Balai Poestaka 1921).

17) One of his stories, Wawatjan Enden Sari-Banon: Tjarios Istri Rajoengan (The Verse Story of Mistress Sari-Banon; A story of naughty lady), was published by Toko Boekoe M.I. Prawira Winata in 1923. His other book, Carita Mantri Djero (The Story of Minister), was published by Balai Poestaka in 1928. 
directly, responding to consumer demand. The contents of the books published by indigenous publishers were less moralistic, the language less artificial, and the stories were more amusing and nationalistic than those in Balai Poestaka's publications, ${ }^{18}$ although the total number of copies of their books was far lower than Balai Poestaka's.

\section{Toko Boekoe M.I. Prawira-Winata: An Indigenous Publisher in Bandung}

Noteworthy among indigenous publishers was the Toko Boekoe M.I. Prawira-Winata, located in the Bandung city center at Poengkoerweg 46. This publishing house was named after its owner Ibrahim Prawirawinata, who was a school principal (mantri guru) at the Lengkong district in the city of Bandung (Figure 5). This publisher edited manuscripts and sent most of its orders to a printing house, N.V. Boekh. Visser \& Co in Bandung. The number of impressions of a title was between 1000 and 2500. For instance, 2500 copies were printed for the popular title Wawatjan Enden Sari-Banon: Tjarios Istri Rajoengan (The Verse Story of Mistress Sari-Banon: A story of a naughty lady) (Figure 6).

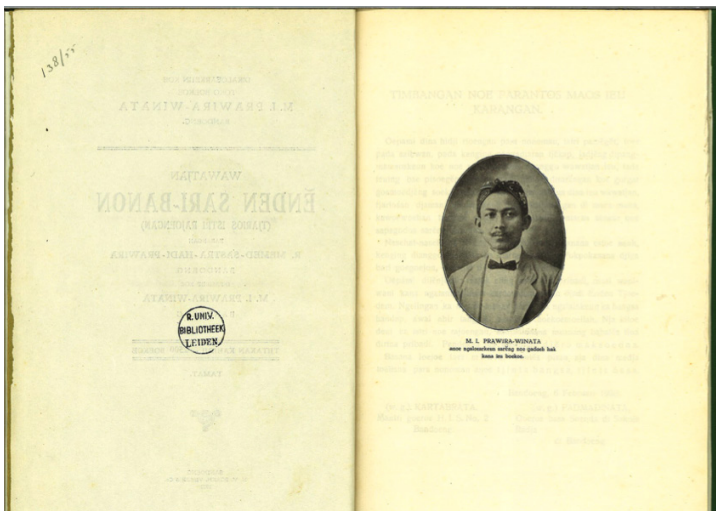

Figure 5. Ibrahim Prawirawinata, owner of Toko Boekoe M.I. Prawira-Winata

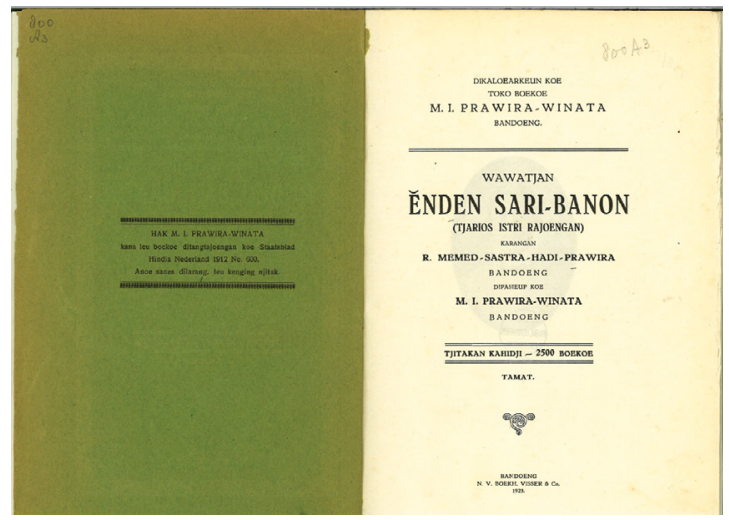

Figure 6. Wawacan Enden Sari-banon, Carios Istri Rajoengan, published in 1923

The total number of titles published by Toko Boekoe M.I. PrawiraWinata was at least fifteen. Editing with usually done by the owner, Prawirawinata. The books were sold for $f 0.50$ to $f 1.25$ each and sent by mail for f0.10 to f0.90, depending on the weight of the book. The cover pages in the front and back usually have lists of all the publisher's titles for sale. The cover page of the second edition of Tembang Sisindiran (The Verse of Sundanese Riddle), published in 1922, lists twenty-three agents in West Java and Batavia that sold the publisher's books. The owner proudly claims that Toko Boekoe

18) Because of these characteristics, people seemed to really love them (Kartini, 1979: 8-10, 61-63). 
M.I. Prawira-Winata is the biggest book agent in the Sundanese-speaking area (Prawira-Winata, 1922: cover page). The last seven pages of the same book list a number of titles for sale in Sundanese and Malay. These titles include the publications of Balai Poestaka too. Advertisements in another book show a few lists for trade that include Malay, Javanese and Dutch publications besides Sundanese ones. As the biggest book agent in the area, this toko boekoe seems to have had a large stock of books in various languages and used to sell various stationery such as fountain pen, envelop and paper.

Some books insert endorsements by various readers both male and female. For instance, we read endorsements of three men in the book Wawatjan Roesiah Noe Geulis (The Story of the Beautiful Woman's Secret): M. Kdr. Natawisastra, a teacher who held school management positions (mantri guru) at a standard school (sakola normaal) in the city of Garut; R. Natadimidjaja, a clerk at S.S. (unknown) in Bandung; and Soepjan Iskandar, a teacher at a standard school (Inlandsch Onderwijzer Normaalschool) in Meester Cornelis in Batavia (Tjandra Pradja [192x]: 2-3). Such endorsements were mostly written by men, but also by women including Tedjaningsih, Djoewariah and Djoelaeha, who were living in Cianjur and recommended the same book. This suggests that there were also literate women who not only read books but made public comments on books arguably as a consequence of the expansion of the colonial school education system in the 1920s. This book seems to have been read by many people, judging from the issuing of its second impression. ${ }^{19}$

Another interesting advertisement was found on the back cover of Wawatjan kangdjĕng Pangeran Soemĕdang (A Story of His Highness the Prince of Soemedang), published in 1922. It reads:

Bodor Ibrahim (Aki-aki Ogoan) (Ibrahim's Funny Way (An Indulged Grandfather)) Price $f 0.50$. Postal fee $f 0.10$. Mr. Djajadikarta in Wanajasa purchased 70 copies; Mr. Soeradidjaja in Benda purchased 50 copies; Mr. M. Koerdi in Tjibatoe purchased 50 copies of BODOR IBRAHIM" (Prawirawinata in Kartadinata, 1922: cover).

The publisher's editor and owner, Prawirawinata, tried to draw readers' attention by mentioning three men who bought multiple copies of the book. This is a rare example of a selling strategy that cannot be found in other publishers' advertisements or Balai Poestaka publications. In short, as an entrepreneur Prawirawinata ran his publishing business quite creatively.

\section{Book Publishing and Colonial Print Culture}

Book publishing seemed to enter a new phase in the Dutch East Indies in

19) This title was published in three volumes: $f 1.25$ each, total 180 pages. If you ordered three books in bound, the price was discounted to $f 3.00$; in special binding the book cost $f 4.00$ and postage was $f 0.40$. 

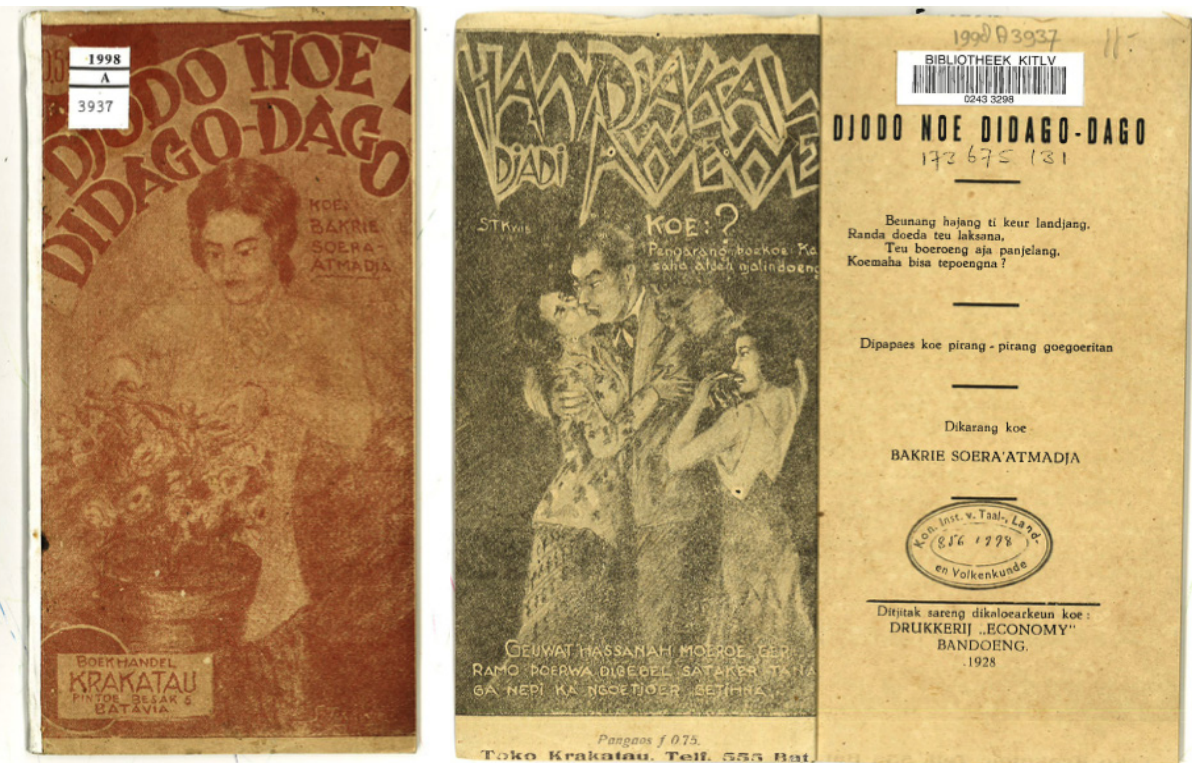

Figure 7. Left: illustration in Djodo Noe didago-dago (Long-awaited Fiancé) published in 1928. Right: advertisement of the same book, Handjakal Djadi Awewe (The Pity of Being A Woman)

the early 20th century with the emergence of a print culture. Difficult as it was, the colonial government tried to monitor indigenous publications and control them through various measures. Discourse in the vernacular media, especially Chinese periodicals, had been monitored by Balai Poestaka since 1912 (Yamamoto 2019: 62-68, 78-91). Authors and publishers did not have unfettered freedom to express their thoughts and creativity, yet tried to circumvent colonial control and bring their publications to a growing readership. For example, even though nationalistic, provocative and suggestive writings were not published by the government-owned Balai Poestaka, indigenous publishers and book agents such as Toko Boekoe M.I. Prawira-Winata provided these writings to its Sundanese readers. There seemed to be various discourses in society. ${ }^{20}$ This sort of print culture might be considered as distinctive, having only come into existence in a colonial context and shaped by the limitations and interests of the colonial government and nationalists.

Despite such limitations, Sundanese authors and publishers tried to realize their aspirations as well as find a way to survive and make money. The director of Boekhandel \& Drukkerij Economy in Bandung expressed his wish to lift the level of Sundanese readings (lectuur), ${ }^{21}$ in a book titled

20) Yamamoto points out that Balai Poestaka tried to "secure hegemony over schooled indigenous youth. A close evaluation of developments in the East Indies publishing industry reveals, however, that such hegemony was never quite realized, thanks in part to the industry's relatively liberal environment" (2019: 156).

21) He says, "Djisim koering anoe teu kinten hajangna ngamadjeungkeun lectuur (aosan) Soenda, soepados tiasa handjat kana tahapan anoe loehoer" ("I really want to 
Djodo noe Didago-dago ( The Long-awaited Fiance) with a sensational illustration advertising another book, Handjakal Djadi Awewe (The Pity of Being A Woman) (Figure 7). An interesting anecdote in this book is when this director tells of when the future first president of the Republic of Indonesia, Soekarno, introduced him to the author Bakrie Soera'atmadja who subsequently agreed to work with him. This anecdote shows that the director had a good relationship with nationalists at that time. A combination of nationalism and secular reading constitutes an interesting feature of Sundanese book publishing in the 1920s and can be regarded as a trait of colonial print culture.

Another example that shows publisher's engagement with the emerging readership in this period can be seen in Prawina-winata's owner in his stated purpose in publishing books:

Now, in modern times, some are wisely guiding the nation by well-organized speech in front of hundreds of people. Others publish a variety of newspapers. As far as I am concerned, I got the right calling in my heart to circulate available books to remote villages where books are far between in order to engage people. I hope sleeping people will wake up soon (bold letters are original).

Koe objagna Djaman Kamadjengan, sapalih noe palinter noengtoen bangsana sareng memeres basana koe djalan lezing di hereupeun magratoes-ratoes djalma. Sapalih deui koe ngaloearkeun roepi-roepi serat kabar. Doepi menggah pribados, anoe kaoentoep koe hate sareng kadada, keur njebarkeun boekoe-boekoe anoe parantos aja, soepados mawoer ka lemboer-lemboer noe singkoer, anoe langka kadjoegdjoeg koe boekoe-boekoe, malahmandar noe talibra enggal beunta (Prawirawinata on the back cover of Tembang Sisindiran, published in 1922).

In the same book he doesn't forget to add, "More books were published as time went by. Half of them are those I have published". This statement amply demonstrates the state of the nationalist movement in the early 20th century as well as the status of publishing of the times: he seems to have been enthusiastic about disseminating modern thought by publishing and circulating Sundanese books.

On the other hand, Prawirawinata had another difficulty for his publishing business. Prefaces of books published by the toko boekoe asked readers to send their work to the publisher. ${ }^{22} \mathrm{He}$ was ready to buy a story

advance Sundanese literature so that it will be able to rise to an exalted level") (Directeur Boekhandel \& Drukkerij Economy in Bakrie Soera'atmadja 1928: [i]).

22) The following request appears in Tembang Sisindiran, published in 1922, "Para Djoeragan anoe kagoengan boekoe bantjangeun, oepami hojong enggal-enggal padjeng, mangga kintoenkeun. Sawangsoelna, oepami para Djoeragan perloe ngagaleuh boekoe naon bae, enggal njeratan ka adres pribados tangtos dipangihtiarkeun (If you gentlemen 
and the author's copyright in cash (Andjoen Gandaprawira, 1923: 44). Still, he never forgot to say that it was much better if you paid the cost of publishing: : $^{23}$ You need to pay an extra fee if you want to print a prospectus and advertisements. In fact, you will make [a] 100\% profit if many people order and buy the book" (Prawirawinata in the back of the title page of Wawatjan Toendjoen Woelan, 1922). His service sounds very professional, and indigenous book publishing ended up becoming a viable business in that society. Most of the books published by Toko Boekoe M.I. Prawira-Winata were edited (dipasieup) by Prawirawinata himself. ${ }^{24} \mathrm{He}$ edited not only spelling but also phrasing, diction and the metres in traditional poems (dangding). He also stated that the publisher carefully follows the spelling system provided by the government because recently many poorly-edited books are seen everywhere, which is humiliating to the author. ${ }^{25}$ Toko Boekoe M.I. PrawiraWinata's publication of books constitutes just one single case study among many indigenous publishers in the period. It is interesting because this advertisement concretely illustrates the process, cost and editing of a book.

A modern readership is considered to have emerged in Dutch East Indies societies in the early 20th century. The aforementioned director of Drukkerij Economy in Bandung tells of the existence of subscribers for the literary magazine Hiboerankoe (My Pastimes). ${ }^{26}$ The author of the book

have any drafts for reading and hope for them to be sold well at once, please send them [to me]. On the other hand, if you gentlemen need to buy any books, please send a letter to my address quickly so that I will certainly do my best [to meet your request])".

23) The cost of publishing a 16-page book is $f 85$ and the cost of binding is $f 35$. If you want to publish 1000 copies of a 48-page book, it costs: $48 / 16 \times f 85+f 35=f 255+f 35=$ $f 290$ (Prawirawinata in the back of the title page of Wawatjan Toendjoen Woelan, 1922).

24) A unique exception was Wawatjan kangdjĕng Pangeran Soemĕdang, published in 1922. He says "Ieu wawatjan dihadja koe pribados teu didangkosan, boh margaoejoena dangding, boh basana. Noe dimaksad, soepados koe sadaja kaoeninga bentenna boekoe anoe dipasieup sareng noe teu dipasieup koe Toko Boekoe M. I. Prawira - Winata. Sadjabina ti eta, noe mawi teu dipasieup teh, bilih robah hartosna tina asalna, reh ieu mah Wawatjan Kandjeng Pangeran Soemedang, bilih koemaonam. (This verse story was consciously not edited by me in terms of both verse forms and language. I mean you will see the difference between edited writing and non-edited one by Toko Boekoe PrawiraWinata. Besides this, I am afraid that editing cause a change of meaning to the original, because this verse story is the Verse Story of Your Highness of Prince of Sumedang. I am afraid something wrong happens)" (bold is original).

25) The original text reads "Marios atoeran njeratna (spelling), doemoegi ka leresna pisan, noemoetkeun atoeran anoe parantos ditangtoskeun koe Goepernemen. Oelah sapertos anoe parantos kapendak njeratna karangan teh sakama-kama bae. Hal ieu, kantenan matak ngahinakeun ka noe ngarangna. (Checking the rule of spelling is important, because it is very good to follow the rules provided by the government. Do not be like careless writings found recently. This certainly causes to humiliate those who create writing)" (M.I. Prawira-Winata in the back of the front cover of Wawatjan Toendjoen Woelan, published in 1922)

26) This magazine may have been written in Malay but subscribers included readers of Sundanese books. 
Djodo Noe Didago-dago (same publisher) was one of the subscribers of the magazine. ${ }^{27}$ Hence the literate nurtured by the Dutch school came to read both Sundanese and Malay, so the Sundanese readership overlapped with the Malay and Dutch readerships.

Another author recommends that his readers take a book Guide for Fortune (Boekoe Pitoedoeh Karahajoean) in their pocket (saku) and read it at least once a week so that the contents can be understood well (M. Partadiredja $19[X X]: 4)$. The author of this book, Partadiredja, was a Sundanese language teacher at a school for aristocrats in Bandung (Sakola Menak Bandung). ${ }^{28}$ This advice shows that people were used to bringing a book with them when they went out and books had become a commodity in their daily life.

Another recommendation in the preface of a book is intriguing. It reads: "The language is well-written and sweet. It is quite appropriate to put this book on the writing desk of youth who love nation and language". ${ }^{29}$ The phrase "youth who love nation" (para nonoman anoe tjinta bangsa) reflects the atmosphere of the nationalist movement of the time. Books were put on the writing desk. Printed books and a writing desk represented modernity in the daily life of the literate population. Colonial print culture kept growing in the Dutch East Indies in the early 20th century.

\section{Conclusion}

The indigenous book publishing business for Sundanese-speaking communities started in the early 20th century, when the nationalist movement was set in motion. The modern school system had continued to spread in colonial society from the mid-19th century. The more education spread, the more literate people there were among the indigenous population. The indigenous book publishing business responded to the demands of this newlyemerging readership. Book publishing finally turned into a business by the 1920s. It seems to have provided distinctive readings from those provided by Balai Poestaka. The indigenous publishers played a supplemental role in nurturing print culture in the colonial context.

They produced a different type of reading and print culture than the government's in terms of content, quality, advertising style and distribution.

27) Additionally, the director offered an exclusive package of nine books at a discount price of $f 2.00$ instead of $f 4.85$ to readers of that book (Soeria'atmadja, 1928:3).

28) Possibly it meant the Training School for Indigenous Officials (OSVIA: Opleidingsschool voor Inlandsche Ambtenaren). This school changed its name in 1901 from the School for Nobility (Sakola menak or Hoofdenschool) to OSVIA, but it seems to have continued to have been known by its old name sakola radja.

29) This recommendation in Wawatjan Enden Sari Banon was made by two teachers (Mr. Kartabrata, managing teacher Mantri goeroe H.I.S. No. 2 Bandung and Mr. Padmadinata, Sundanese teacher at Sakola Radja- Hoofdenschool, which became OSVIA in 1900 ) in Bandung). The original text reads "Basana loejoe toer manis. Pantes pisan aja dina medja toelisna para nonoman anoe tjinta bangsa, tjinta basa” (Sastrahadiprawira 1923:5). 
They did however, follow the spelling system regulated by the authority. Some authors created stories and had them published without discriminating between private indigenous publishers and the government-owned Balai Poestaka. Both government and private indigenous publishers contributed to promote modern readership and a colonial print culture. However, the publications of the indigenous publishers were not as didactic and moralistic as those from the colonial authority in terms of content. It can be said that the book publishing and print culture in regional languages like Sundanese were nurtured in the colonial period and grew to constitute a medium to decolonize knowledge and knowledge culture.

Sundanese books are still published nowadays. At least 2200 books have been published since the first book in Sundanese was published in 1850. In the 21 st century most Sundanese books are produced by private publishers rather than the government. Modern Sundanese print culture has its roots in colonial knowledge culture, but the Sundanese have made their contribution to it since the early 20 th century through their participation in book publishing.

\section{References}

Anonymous (1918). 'Schets van een Werkprogramma voor de Commissie voor deVolkslectuur'. Vrijzinnig Weekblad 26: 425-428.

Anonymous (1963). 'Het werk van de Commissie voor de Volkslectuur in Nederlandsch Indië', (Appendix to an official letter of the Minister of Colonial Affairs tot he Queen, 26 February 1926) in S.L. van der Wal, Het onderwijsbeleid in Nederlands-Indië 1900-1940. Groningen: n.p., 404-409.

Balai Poestaka (1921). Daftar Kitab-kitab jang dikeloerkan oleh Komisi Balai Poestaka di Weltevreden (Daftar Jang Kelima). Batavia: G. Kolff \& Co.

Balai Pustaka ([1948]). Balai Pustaka Sewadjarnja 1908-1942. Djakarta: Balai Pustaka.

Bataviaasch Genootschap van Kunsten en Wetenschappen (1886). 'Bijlage VIII. Lijst der leden van het Genootschap op ultimo December 1885', Notulen van de Algemeene en Bestuurs-verga-deringen van het Bataviaasch Genootschap van Kunsten en Wetenschappen Deel XXIII: 57-62.

Bureau voor de Volkslectuur (Balai Poestaka) (1924). Resultaten van de Volkslectuur in het jaar 1922. Batavia: Bureau voor de Volkslectuur.

Commissie voor de Volkslectuur (1912). Palanggeran Noeliskeun Basa Soenda koe Aksara Walanda. Batavia: Commissie voor de Volkslectuur.

Departement van Gouvernementsbedrijven in Nederlandsch-Indië (1912). Landsdrukkerij Verslag over 1911. Batavia: Landsdrukkerij.

Ekadjati, E.S. (1996). 'Cultural Plurality: The Sundanese in West Java', in Ann Kumar and John H. McGlynn (eds). Luminations. Jakarta: The Lontar Foundation, New York \& Tokyo: Weatherhill, Inc.

Groeneboer, Kees (1993). Weg tot het Westen: het Nederlands voor Indie 1600-1950 een taalpolitieke geschiedenis. Leiden: KITLV Uitgeverij.

Hassert, J.M. van (1938). 'Het kantoor voor de Volkslectuur'. Bibliotheekleven 23: 122-126. 
Hutagalung, Ridwan. ([2013]). “Beberapa Toko Buku Tempo Dulu di Bandung”, in Web Cite Mooibandoeng: Senantiasa belajar kenal dan cinta kota Bandung. https://mooibandoeng.com/2013/06/28/beberapa-toko-buku-tempo-duludi-bandung/ (accessed 20-8-2018).

Kantoor voor de Volkslectuur (1931). Eenige Resultaten van de Arbeid in het jaar 1930. Batavia: Volkslectuur.

Kartini, Tini; Hadish, Yetty Kusmiyati; Sumardipura, Sutedja; Iskandarwassid (1979). Yuhana - Sastrawan Sunda. Jakarta: Pusat Pembinaan dan Pengembangan Bahasa, Departemen Pendidikan dan Kebudayaan.

Kuitert, Lisa (1993). Het ene Boek in Vele delen: De Uitgave van Literaire Series in Nederland 1850-1900. Amsterdam: De Buitenkant.

Kuitert, Lisa (2001). "Famous, Beloved and Best-Selling. On Sales Methods and Literary History”, in Jacques Michonen Jean-Yves Mollier (eds). Les Mutations du Livre et de l'edition dans le monde. Paris/Quebec: Les Presses de l'Université Laval, pp. 183-191.

Landsdrukkerij (1853). Algemeen Verslag van den Staat van het Schoolwezen in Nederlandsch-Indie onder ultimo december 1852. Batavia: Landsdrukkerij.

Maier, H.M.J. (1993). 'Boredom in Batavia: A Catalogue of Books in 1898', in: D.M. Roskies (ed). Text/politics in Island Southeast Asia, Essays in Interpretation. Athens \& Ohio: Ohio University Center for International Studies, pp. 131-156.

Maters, Mirjam (2003). Dari Perintah Halus ke Tindakan Keras: Pers Zaman Kolonial antara Kebebasan dan Pembarangusan, 1906-1942. Jakarta: KITLV-Jakarta; Hasta Mitra; Pustaka Utan Kayu.

Meer, Arnout H.C. van der. (2017). "Performing Colonial Modernity: Fairs, consumerism, and the Emergence of the Indonesian Middle Classes", Bijdragen tot de Taal-, Land- en Volkenkunde 173(4): 503-538.

Moriyama, Mikihiro (1995). 'Language policy in the Dutch colony: on Sundanese in the Dutch East Indies', Southeast Asian Studies 32 (4): 446-54.

Moriyama, Mikihiro (2005). Sundanese Print Culture and Modernity in $19^{\text {th }}$ Century West Java. Singapore: Singapore University Press.

Moriyama, Mikihiro (2013). Semangat Baru: Kolonialisme, Budaya Cetak, dan Kesastraan Sunda Abad Ke-19, versi revisi. Jakarta: Komunitas Bambu.

Moriyama, Mikihiro (2017). 'Jasa Balai Pustaka dalam Pembentukan Literasi pada Abad ke-20: Suatu Tinjauan dari Penerbitan Buku-buku berbahasa Sunda', in Koko Sudarmoko (ed). Seratus Tahun Balai Pustaka (1917-2017). Jakarta: Balai Pustaka, pp. 11-25.

Rosidi, Ajip (1966). Kesusastran Sunda Dewasa Ini. Bandung: Tjupumanik.

Siregar, Bakri (1964). Sedjarah sastera Indonesia modern. Jakarta: Akademi Sastera dan Bahasa Multatuli.

Teeuw, A (1972). 'The impact of Balai Pustaka on modern Indonesian literature', The Bulletin of the School of Oriental and African Studies, University of London 35, 1: 111-127.

Termorshuizen, Gerard and Anneke Scholte (2011). Realisten en reactionairen: een geschiedenis van de Indisch-Nederlandse pers 1905-1942. Amsterdam: Nijgh \& Van Ditmar; Leiden: KITLV Uitgeverij.

Tjiook-Liem, Patricia (2009). De rechtpositie der Chinezen in Nederlands-Indië 18481942: Wetgevingsbeleid tussen beginsel en belang. Leiden: Leiden University Press.

Universitaire Biblioteken Leiden (2014). Universitaire Biblioteken Leiden Jaarverslag 
2014. Leiden.

Yamamoto, Nobuto (2019). Censorship in colonial Indonesia, 1901-1942. Leiden \& Boston: Brill. 